\title{
HERDENKING VAN Dr. G. P. ROUFFAER.
}

\section{Aanvulling der opgave zijner publicaties.}

De op blz. 288 e.v. hiervóór opgenomen lijst van publicaties van Dr. Rouffaer moet nog worden aangevuld met de navolgende titels. welke door mij bij de samenstelling over het hoofd zijn gezien.

Mededeelingen naar aanleiding van „Over Koedjang en Badi“ van Dr. C. Snouck Hurgronje en over ,.Koedi en Tjoendrik” van Dr. G. A. J. Hazeu. (Notulen Bat. Gen. XI.III, 1905, blz. IV-VII).

Tentoonstelling van Oost- en West-Indisch bewerkt metaal. (Tijclschrift voor Ned.-Indië, 2e N.S., 4e jaarg., 1900, blz. 543-546).

Schrijven aan de Directie van het Bat. Gen. v. K. en W. over: I. Oud-Javaansche inscriptie in Soembawa. - II. Curiosa der onderafdeeling Ngada, Midden Flores. Net platen en tekstillustratie (Notulen Bat. Gen. XLVIII, 1910, bl. 110-119).

D1. 84 . 
